\title{
Translucent Zirconia Restorations: A Case Report
}

\author{
Hoda Gaafar Hassan Hammad* \\ Department of Restorative Dentistry-Dental Materials, Misr University for Science and Technology, Egypt
}

Submission: November 06, 2017; Published: January 22, 2018

*Corresponding author: Hoda Gaafar Hassan Hamma, Department of Restorative Dentistry-Dental Materials, Misr University for Science and Technology, Egypt, Tel: 1147414661; Email: dr.hodahammad@gmail.com

\begin{abstract}
Durable restorations that maintain tooth's integrity, high strength, and excellent natural appearance can be achieved using high strength dental ceramics. Recent CEREC technology allows in one visit designing and milling of indirect restorations with a strong base structure such as Zirconia. In this case report, a 43-year-old female patient came to the clinic aiming to alter her maxillary teeth and to get beautiful natural smile. On clinical examination, she had previous dental treatment since many years with PFM. The case was properly studied; the newly invented translucent Zirconia was fabricated with very successful results.
\end{abstract}

\section{Introduction}

Porcelain fused to metal restoration systems are considered a high-strength treatment modality associated with durable success, however; they had certain disadvantages, mainly in terms of aesthetics and biocompatibility [1]. Over the past decade, patient's expectations of esthetic are highly progressing and variable novel all-ceramic systems have been developed.

Actually; rapid improvements in high-strength all-ceramic technology have been achieved with the rise of Computer-Aided Design/ Computer-Aided Manufacturing (CAD/CAM) systems, like the high translucency Zirconia [2-4]. The CAD/CAM design and manufacture of these ceramic restorations involves optical 3-dimensional scanning and digitizing of the dies; in order to precisely duplicate the prepared margins of the abutment teeth. Then, the obtained scanned 3-dimensional images of the dies are used to design the substructure of the permanent all-ceramic restoration that is prompted by computer software [1].

Fortunately; durability and clinical evaluation reports of all-ceramic prosthetics are promising [2]. For recent ceramics, reports have confirmed a success rate of about $98.4 \%$ of clinical service of more than 5 years [3]. The following report describes the restoration of full arch maxillary teeth with Lava zirconia allceramic system.

\section{Case Report}

A 43-year-old female patient came to the clinic complaining from unpleasant smile and esthetic of her maxillary teeth. Patient was medically free, smoker and had good oral hygiene. On clinical examination, the maxillary central incisors were discolored, and possessed generalized inter dental spaces with central diastema. Moreover, metal show and open margin of all PFM (Porcelain Fused to Metal) restorations of teeth number 2, 3, 4, 5, 13, 14 and
15 were noted. The maxillary right first premolar was previously root canal treated and discolored by effect of a huge amalgam restoration. Primary casts for upper and lower jaws were prepared as well as a panoramic radiograph was get for case study, diagnostic wax up and treatment planning.

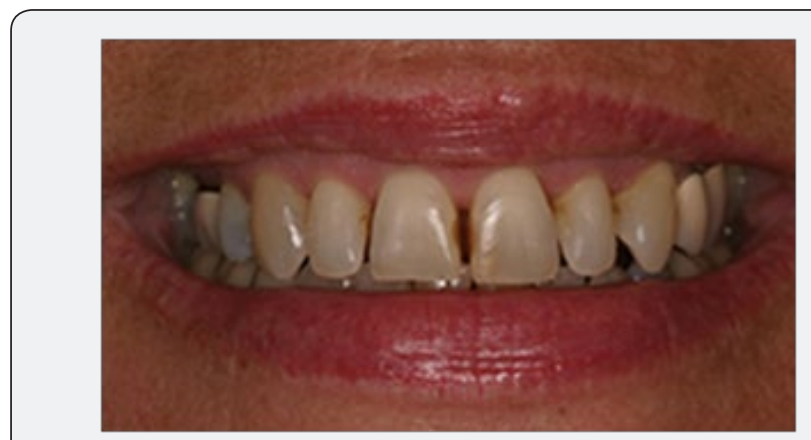

Figure 1: Preoperative view.

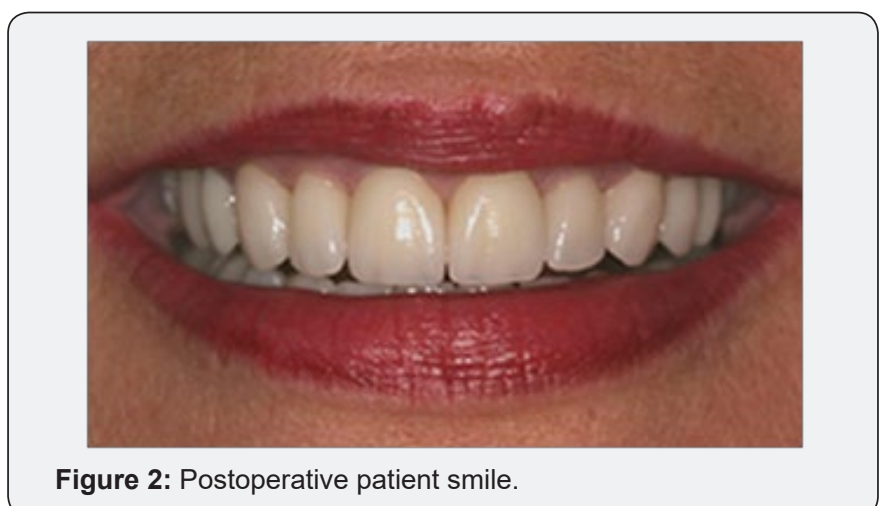

Provisional restoration was constructed for the patient, face bow registration was recorded and shade for the final restoration was selected with a spectrophotometer. The teeth were prepared, 
Zirconia full ceramic crowns were constructed, the fitting surface was treated, acid etched with Hydrofluoric acid and coated with Silane coupling agent. The tooth surfaces of abutments were acid etched with Orthophosphoric acid for cementation with resin cement having a shade matching the restoration (Figure $1 \& 2$ ). Patient was followed up for more than 6 months; she was very happy, felt self-confident of her smile and liked the successful outcome that was built on long-lasting function and wonderful aesthetic natural appearance.

\section{Discussion}

Smile is highly affecting the psychology and social life of peoples. Aesthetic is developing rapidly with the nano-technology in dental treatment $[1,5]$. The main problem of previous zirconia was opacity and debonding of its porcelain laminates [6]. In this case the female patient gained a lot from the high translucency Zirconia restoration; very nice esthetic appearance, long-lasting high strength, good bonding with tooth structure owing to the silanization process and nano resin cements $[4,7]$.

\section{References}

1. Barnfather KD, Brunton PA (2007) Restoration of the upper dental arch using Lava all-ceramic crown and bridgework. Br Dent J 202(12): 731735

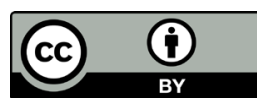

This work is licensed under Creative Commons Attribution 4.0 Licens DOI: 10.19080/ADOH.2018.07.555715
2. Zitzmann NU, Galindo ML, Hagmann E, Marinello CP (2007) Clinical evaluation of Procera AllCeram crowns in the anterior and posterior regions. Int J Prosthodont 20(3): 239-241.

3. Haselton DR, Diaz-Arnold AM, Hilis SL (2000) Clinical assessment of high-strength all-ceramic crowns. J Prosthet Dent 83(4): 396-401.

4. Robert G Ritter (2013) Use of High Translucency Zirconia in the Aesthetic Zone. Dentistry Today Category: Restorative Created: Monday 16 September 14: 43.

5. Erik Unosson, Ingrid Ajaxon, Johanna Engstrand, Håkan Engqvist, Wei Xia, et al. (2012) Nano grain sized zirconia-silica glass ceramics for dental applications. Journal of the European Ceramic Society 32 (16): 4105-4110.

6. Doi M, Yoshida K, Atsuta M, Sawase T (2011) Influence of pre-treatments on flexural strength of zirconia and debonding crack-initiation strength of veneered zirconia. J Adhes Dent 13(1): 79-84.

7. Lee Y, Kim JH, Woo JS, Yi YA, Hwang JY, et al. (2015) Analysis of Self-Adhesive Resin Cement Microshear Bond Strength on LeuciteReinforced Glass-Ceramic with/without Pure Silane Primer or Universal Adhesive Surface Treatment. Biomed Res Int 2015: 361893.

\section{Your next submission with Juniper Publishers will reach you the below assets}

- Quality Editorial service

- Swift Peer Review

- Reprints availability

- E-prints Service

- Manuscript Podcast for convenient understanding

- Global attainment for your research

- Manuscript accessibility in different formats

( Pdf, E-pub, Full Text, Audio)

- Unceasing customer service

Track the below URL for one-step submission https://juniperpublishers.com/online-submission.php 